\title{
The difference of PGE2 and COX-2 expressions in various histological grading of endometrial endometrioid carcinoma
}

\author{
Yusfita Efi Rosdiana, Willy Sandhika \\ Anatomic Pathology Department, Faculty of Medicine Airlangga University, Dr. Soetomo Hospital, Surabaya
}

\begin{abstract}
ABSTRAK
Tujuan: Menganalisis ekspresi PGE2 dan COX-2 pada berbagai derajat diferensiasi sel secara histologis pada karsinoma endometrioid endometrium.

Bahan dan Metode: Penelitian observasional analitik dilakukan pada sampel blok parafin karsinoma endometrioid endometrium derajat diferensiasi histologik 1,2 dan 3 pada laboratorium Patologi Anatomik RSU Dr. Soetomo. Pemeriksaan ekspresi PGE2 dan COX-2 menggunakan teknik imunohistokimia dengan antibodi PGE2 dan COX-2.

Hasil: Terdapat perbedaan peningkatan ekspresi PGE2 pada karsinoma endometrioid derajat diferensiasi 1 dan 2 serta derajat 2 dan 3. Peningkatan ekspresi COX-2 didapatkan pada derajat diferensiasi 1 dan 3 .

Kesimpulan: Penelitian ini menunjukkan adanya peningkatan ekspresi PGE2 dan COX-2 pada karsinoma endometrioid endometrium dengan derajat diferensiasi histologik yang lebih tinggi dibandingkan dengan derajat diferensiasi histologik rendah. (MOG 2017;25:1-5)
\end{abstract}

Kata kunci: karsinoma endometrioid endometrium; derajat diferensiasi sel; PGE2; COX-2

\begin{abstract}
Objectives: to analyze the expression of PGE2 and COX-2 in various histological grade of endometrial endometrioid carcinoma. Materials and Methods: Analytical observational study was performed on parafin block archives of endometrial endometrioid carcinoma with histological grade 1,2 and 3 in Anatomic Pathology laboratory Dr. Soetomo hospital. PGE2 and COX-2 expression were examined by immunohistochemical staining using PGE2 and COX-2 antibodies. The results were analyzed statistically.

Results: There were increase of PGE2 expressions of in endometrioid carcinoma grade 2 compare to grade 1 and grade 3 compare to grade 2 . The COX-2 expression was increase in histologic grade 3 compare to grade 1 .

Conclusion: The expression of PGE2 and COX-2 in endometrial endometrioid carcinoma were increased in higher histologic grade compare to lower histologic grade. (MOG 2017;25:1-5)
\end{abstract}

Keywords: endometrial endometrioid carcinoma; histologic grade; PGE2; COX-2

Correspondence: Willy Sandhika, Anatomic Pathology Department Faculty of Medicine Airlangga University, email: willysand@fk.unair.ac.id phone +628123293120 .

\section{INTRODUCTION}

Endometrioid carcinoma of endometrium is ranked sixth in female reproductive organs malignancy. There were hundred thousands new cases each year, with the seventh leading cause of death in female cancer. The most frequent type of endometrial carcinoma found is adenocarcinoma (85\%), endometrioid type. The greatest incidence of endometrial carcinoma is in postmenopausal women, with $86 \%$ aged over 50 years. ${ }^{1,2,3}$

According to the histologic subtype, endometrioid carcinoma of the endometrium is divided into several degrees of cell differentiation. ${ }^{4}$ The degree of cell differentiation 1, with the criterion of solid component $\leq$ $5 \%$. Degree of cell differentiation 2, with solid component criteria $6-50 \%$. Degree of cell differentiation 3, with solid component criterion $>50 \% .^{5}$ The higher the degree of differentiation, the aggressiveness of the tumor increased. $6,7,8,9$

PGE2 inflammatory mediator is a prostaglandin bioactive that plays a role in the process of tumori-genesis, producing prostanoids in which closely related to estrogen. Pathogenesis of endometrioid endometrial carcinoma is estrogen dependent type. ${ }^{3,9} \mathrm{COX}-2$ is one of the catalytic enzymes in the prostaglandin biosynthesis process. COX-2 affects many important processes in carcinogenesis. In epithelial cells that have expression of COX-2 increased, they show higher rates of proliferation and inhibition of apoptosis. This results in increased COX-2 expression in the higher degree of differentiation of endometrioid endometrial carcinoma.

The relationship between endometrial carcinoma and inflammation is mentioned by Wallace et al., That the hormonal changes in endometrial carcinoma formation stimulate the tumor microenvironment, one of which is the localized inflammatory environment. ${ }^{1}$ This stimulates the production of PGE2 and COX-2 as one of the inflammatory mediators. There is still a few study of the expression and role of PGE2 and COX-2 as well as its association with endometrioid endometrial carcinoma. ${ }^{6,10}$ 
This study aims to prove the difference of PGE2 and COX-2 expression in different degrees of cell differentiation histologically in endometrioid carcinoma of endometrium.

\section{MATERIALS AND METHOD}

In this research, paraffin blocks were collected from archives of Anatomical Pathology laboratory of Dr. Soetomo Surabaya, during the period of January 2014 to December 2015. They were taken randomly, consist of 30 paraffin blocks of endometrial endometrioid carcinoma patients, divided into 10 samples in the degree of histologic differentiation 1,2 and 3 .

PGE2 expression was examined immunohistochemically with rabbit anti-human monoclonal antibodies from Biocare Medical with 1: 100 dilution and rat antihuman COX-2 polyclonal antibody from Bioss with 1: 100 dilution. Expression of PGE2 and COX-2 is positive if it is in the cytoplasm. Positive tumor cells were calculated visually with a 400x enlarged binocular light microscope then an assessment based on the percentage of positive cell counts were performed. The data collected were analyzed statistically. Differences of PGE2 and COX-2 expression were analyzed by Kruskal Wallis test at $95 \%$ significance level.

\section{RESULTS AND DISCUSSIONS}

The results showed the mean age of patients were 52.87 years \pm 8.13 years. The youngest patient aged 31 years old and the oldest was 70 years old. The endometrial endometrioid carcinoma patients were mostly in the age range of 51-60 years (50\%). Epidemiologically, the average age of endometrial endometrioid carcinoma is 63 years. $^{2}$

Table 1. PGE2 expressions in various differentiation degree

\begin{tabular}{|c|c|c|c|c|c|c|c|}
\hline \multirow{2}{*}{$\begin{array}{c}\text { Different } \\
\text { iation } \\
\text { degree }\end{array}$} & \multirow[b]{2}{*}{$\mathrm{n}$} & \multicolumn{5}{|c|}{ PGE2 expressions } & \multirow[t]{2}{*}{$\mathrm{p}$} \\
\hline & & $\mathrm{X}$ & SD & Median & Min & Max & \\
\hline 1 & 10 & 75,50 & 14,62 & $80,00^{\mathrm{a}}$ & 40 & 90 & \\
\hline 2 & 10 & 87,50 & 3,54 & $90,00^{\mathrm{b}}$ & 80 & 90 & $0,000 *$ \\
\hline 3 & 10 & 93,10 & 6,87 & $95,00^{\mathrm{c}}$ & 75 & 98 & \\
\hline
\end{tabular}

Description : * significant in $\alpha=0,05$ (Kruskal-Wallis test)

a, b, c different superscripts showed differences between group

In this study, PGE2 expression was calculated on each histologic differentiation degree and the results were obtained as follows: the average of the median on histologic differentiation degree 1 was $80.00 \% \pm$ $14.62 \%$, histologic differentiation degree 2 was $90.00 \%$ $\pm 3,54 \%$, and the histologic differentiation degree 3 was $95.00 \% \pm 6.87 \%$.

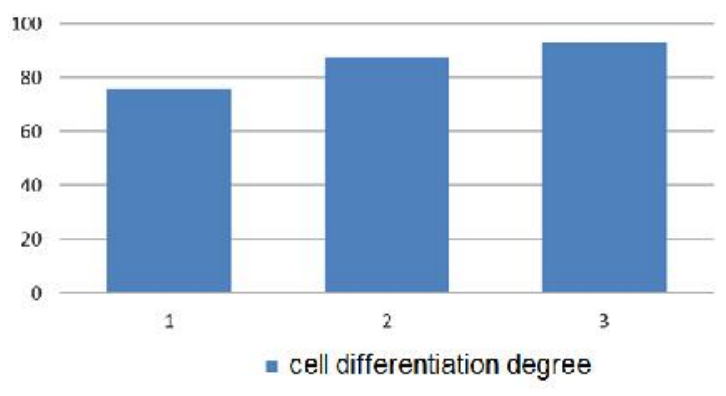

Figure 1. PGE2 expression in various differentiation degrees of carcinoma cell.

Kruskal-Wallis statistical analysis based on median values obtained significant differences in PGE2 expression in each histological group of endometrial endometrioid carcinoma 1,2 and 3 with $\mathrm{p}<0.05$ ( $\mathrm{p}=$ 0,000 ). There was a significant increase in PGE2 expression in the histologic differentiation degree 2 compared to degree 1 , and there was a significant increase in PGE2 expression in the histologic differentiation degree 3 compared with degree 2 .

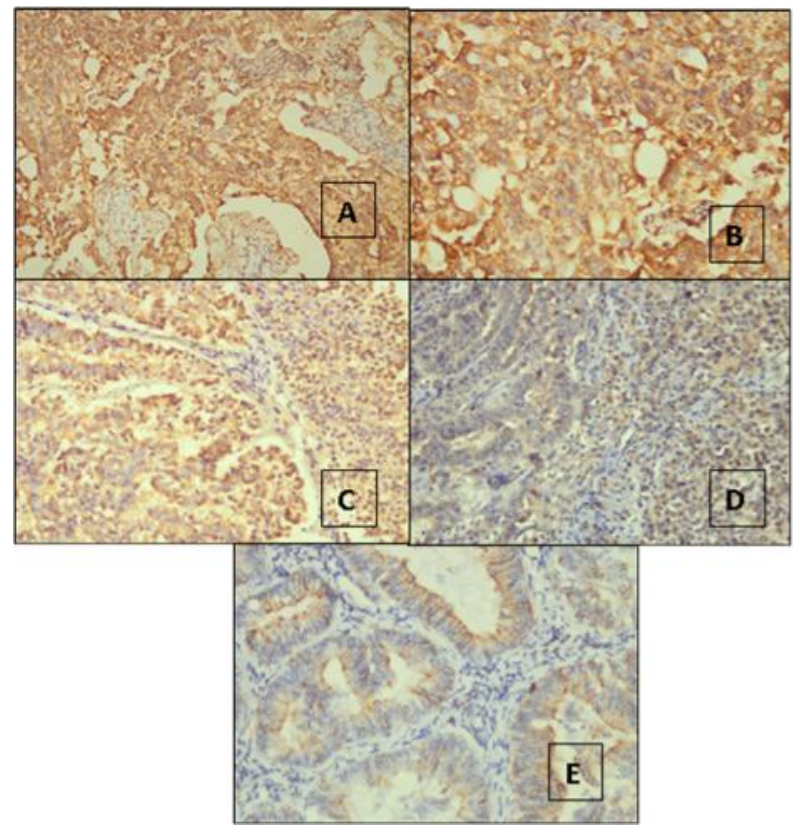

Figure 2. Distribution of PGE2 expression by percentage. Endometrial endometrioid carcinoma differentiation degree 3 (A \& B), Endometrial endometrioid carcinoma differentiation degree 2 (C \& D), Endometrial endometrioid carcinoma differentiation degree $1(\mathrm{E})$ 
There is an increase in PGE2 expression in the higher degree of cell differentiation compared with lower cell differentiation in accordance with previous studies which had increased PGE2 expression in endometrial carcinoma. This suggests that PGE2 participate in the tumorigenesis of endometrium cancer. ${ }^{10,11}$ PGE2 is formed from the metabolism of arachidonic acid and mediated by COX-2, resulting in the biosynthesis of $\mathrm{PG}$ (G2) that is converted into PGH2. PGH2 is metabolized into PGE2 and activate prostanoid receptors $\mathrm{E}$ and $\mathrm{F}$ which have the biological function to endometrium by inducing the expression of estrogen receptors that play a role in the pathogenesis of endometrial endometrioid carcinoma. Other researchers have suggested that the more the aggressivity of the tumor, the higher the expression of PGE2. ${ }^{10,12}$

Endometrioid carcinoma is mainly influenced by estrogen hormone that was mentioned Wallace et al., which stated that estrogen promotes the proliferation and vascularization of the endometrium, it encourages hyperplasia and increases carcinoma endometrium risk. ${ }^{1}$ It is suspected that PGE2 plays a role in the endometrial endometrioid carcinoma response to estrogen (Jarzabek et al.) And PGE2 via prostanoids and their receptors are closely related to estrogen. Based on its pathogenesis endometrial endometrioid carcinoma is an estrogen dependent tumor. ${ }^{12}$

Table 2. COX-2 expression distribution in various differentiation degree

\begin{tabular}{ccccccc}
\hline \multirow{2}{*}{$\begin{array}{c}\text { Differentia } \\
\text { tion degree }\end{array}$} & $\mathrm{n}$ & \multicolumn{3}{c}{ PGE2 expressions } & $\mathrm{p}$ \\
\cline { 3 - 7 } & & $\overline{\mathrm{x}}$ & $\mathrm{SD}$ & $\mathrm{Min}$ & $\mathrm{Max}$ & \\
2 & 10 & $50,00^{\mathrm{a}}$ & 22,73 & 10 & 80 & \\
3 & 10 & $62,00^{\mathrm{ab}}$ & 17,83 & 30 & 85 & $0,000^{*}$ \\
& 10 & $73,50^{\mathrm{b}}$ & 17,96 & 40 & 90 & \\
\hline
\end{tabular}

Description : * significant in $\alpha=0,05$

${ }^{\mathrm{a}, \mathrm{b}}$ different superscripts showed differences between group

Meanwhile, according to the calculation of COX-2 expression in each sample group, the mean percentage of COX-2 expression on histologic differentiation degree 1 was $50.00 \% \pm 22.73 \%$ with the lowest $10 \%$ and the highest $80 \%$, on histological differentiation degree 2 was $62.00 \% \pm 17.83 \%$, the lowest $30 \%$ and the highest $85 \%$, whereas on histological differentiation degree 3 the percentage of COX-2 expression was $73.50 \% \pm 17.96 \%$, the lowest $40 \%$ and the highest $90 \%$.

The statistical test to determine the differences in the expression of $\mathrm{COX}-2$ in various carcinoma cells histological differentiation degrees showed differences in the expression of COX-2 significantly on the histological differentiation degree carcinoma 1 and $3 \mathrm{p}$ $<0.005(\mathrm{p}=0.042)$.

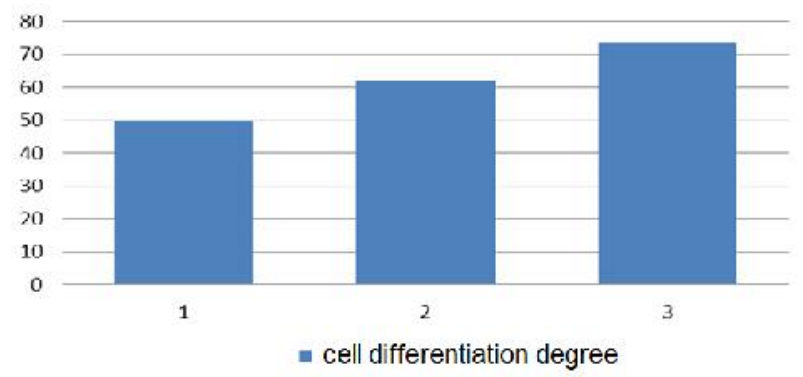

Figure 3. COX-2 expression distribution in various differentiation degree

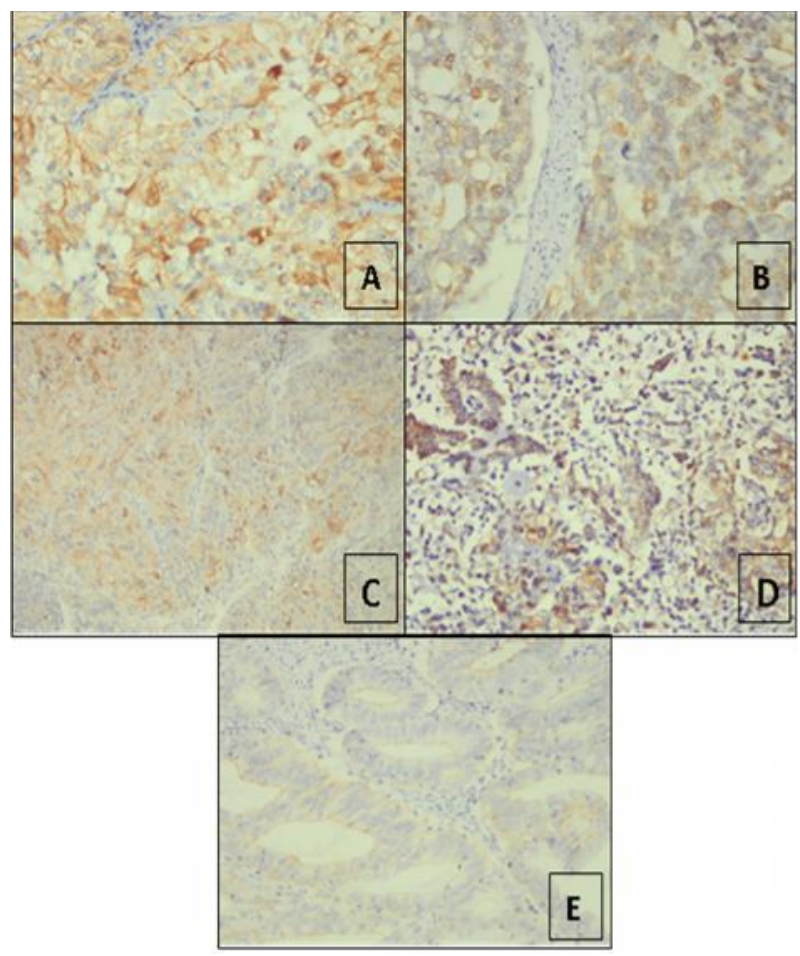

Figure 4. COX-2 positive in the cytoplasm of endometrial endometrioid carcinoma tumor cells. (A) degree of differentiation 3, (b) degree of differentiation 3, (c) degree of differentiation 2, (D) degree of differentiation 2 , (e) degree of differentiation $1.400 \mathrm{x}$ magnification.

There was an increase in COX-2 expression in the histologic differentiation 3 cell group compared with the histologic differentiation 1 cell group, linear to previous studies which found an increase in COX-2 expression at worse degree of differentiation. The degree of histologic differentiation of carcinoma cells predicts clinical outcomes and modalities of treatment planning in patients with endometrial carcinoma, although not yet 
an accurate predictor. Assessment of biological factor expression abnormalities is more likely to link the biology of tumor cells and tumor aggressiveness. ${ }^{9,10,11,13}$

COX-2 is more expressed in endometrial carcinoma than normal endometrial cells. The progressive increase of COX-2 expression in carcinoma versus normal epithelial or prenoplastic lesions, suggesting that the increasing regulation of COX-2 expression may play a role in cancer and its progression. It was found that in endometrial carcinoma cell differentiation degree 3 the postive expression was higher than differentiation degree 2 or degree of cell differentiation 1, which is in line with previous studies that showed that the high expression of COX-2 can be identified in a more agressive endometrial carcinoma. ${ }^{9,10}$

Our study found a relationship of inflammatory mediators with endometrial endometrioid carcinoma. The results showed significant differences in COX-2 expression at differentiation degree 1 and 3 . While PGE2 expression showed significant differences between each group of differentiation degrees. This may be because COX-2 plays a role earlier than PGE2 in inflammatory reactions. COX-2 is an enzyme that acts as a catalyst in the PGE2 biosynthesis process. ${ }^{1.9}$

The higher the degree of differentiation, the more aggressive the tumor increases. This is closely related to the tumor microenvironment, so that many inflammatory mediators are released. The tumor cells secrete cytokines, chemokines and EGF. Cytokines will induce cyclooxygenase enzymes. ${ }^{6,7}$ The condition of neoplasmic malignancy will stimulate arachidonic acid release from the phospholipid membrane mediated by phospholipase A2 enzyme. Arachidonic acid is oxygenated by COX-2 into prostaglandin $\mathrm{G} 2$, which will be reduced to a prostaglandin mediator ( $\mathrm{PGH} 2)$, which is converted to PGE2 and PGD2. ${ }^{8}$ Alleged that PGE2 and COX-2 does not directly affect the degree of histological differentiation of endometrial endometrioid carcinomas but through the increased tumor aggression. Past research had found that the expression of PGE2 and COX-2 was increased in more aggressive tumors. Increased tumor aggressiveness refers to the higher tumor histological differentiation. . $^{70,13,14}$

\section{CONCLUSION}

Our study found an increase in PGE2 and COX-2 expression in cell differentiation degree 3 compared to cell differentiation degree 1 . This suggests a close relationship between inflammatory mediators and the degree of histologic differentiation of carcinoma cells. Endometrial endometrioid carcinoma with higher histo- logical differentiation degree will express PGE2 and COX-2 higher compared with endometrial endometrioid carcinoma with lower histological differentiation degree.

\section{REFERENCES}

1. Kasper LD, Eugene B, Antony SF, et al. Harrison's Principles of internal medicine. 16th Eds. McGrawHill Companies; 2005. p. 1715-21.

2. Raz S and Larissa R. Urinary tract infection in women. Female Urology. 3rd Eds. Philadelphia: Saunders Elsevier; 2007. p. 847-56.

3. Raz R. Urinary tract infection in postmenopausal women. Korean Journal of Urology. 2011;52:8018.

4. Grabe M, Bjerklund-Johansen TE, Botto H, et al. Guidelines on urological infection. European Association of Urology; 2011.

5. Askandar T, Purnomo BS, Djoko S, Gatot S. Infeksi saluran kemih. Buku ajar ilmu penyakit dalam. Surabaya: Airlangga Univ Press; 2007.

6. Dhakal BK, Kulesus RR, Mulvey MA. Mechanisms and consequences of bladder cell invasion by uropathogenic Escerichia coli. Europe Journal of Clinical Investigation. USA: Utah; 2008. p. 2-11.

7. Bien J, Olga S, Przemyslaw B. Role of uropathogenic Escerichia coli virulence factors in development of urinary tract infection and kidney damage. International Journal of Nephrology; 2012.

8. Eigbefoh JO, Isabu P, Okpere E and Abebe J. The diagnostik accuracy of The rapid dipstick Test to predict asymptomatic urinary tract inspection of pregnancy. Journal of Obstetrics and Gynaecology. 2008;28(5):490-5.

9. Arjana S, Chandraker S, Patel VK, Padmini R. Antibacterial activity of medicinal plants against pathogens causing complicated urinary tract infection. Indian Journal of Pharmaceutical science. 2009;71(2):136-9.

10. Junizaf, Budi IS. Infeksi saluran kemih pada wanita. Jakarta: Uroginekologi Indonesia; 2011.

11. Nicolle EL, Suzzane B, Richard C, et al. Infectious disease society of America guidelines for the diagnosis and treatment of asymptomatic bacteriuria in adult. IDSA Guidelines; 2005. p. 643-54.

12. Sunilson JAJ, Suraj R, Rejitha G, et al. In vitro antimicrobial evaluation of zingiber officinale, curcuma long and alpina galang extracts as natural food preservative. American Journal of Food Technology. 2009;4(5):192-200.

13. Hajera T, Mir NA, Noura Al-Jameil and Farah AK. Evaluation of antibacterial potensial of selected plant extracts on bacterial pathogen isolated krom urinary tract infection. International Journal of 
Current Microbiology and Applied Sciences. 2013;2(10):353-68.

14. Malu SP, Obochi GO, Tawo EN and Nyong BE. Antibacterial activity and medicinal properties of ginger. Global Jurnal of Pure and Applied Sciences. 2009;15(3):365-8.

15. Giti O, Marjan G and Fariborz M. Comparation of effects of ginger, mefenamic acid, and ibuprofen on pain in women alt primary dysmenorrhea. The Journal of Alternative and Complementary Medicine. 2009;15(2):129-32.

16. World Heath Organization. Rhizoma Zingiberis. WHO Monographs on Selected Medicinal Plant. 1999;1:227-87.

17. Ambarawati F, Maysarah E, Apriani M and Nurul MBMD. Personal hygine and asymptomatis bacteri-uria in women aged 40-65 years. Universa Medicina. 2011;30(1):54-62.

18. Speroff L, Fritz MA. Menopause and the perimenopausal transition. Clinical Gynecologic Endocrinology and Infertility. 8th Eds. USA: Lippincott Williams \& Wilkins; 2011.

19. Elya EM, Stephen EH, Delia S, et al. Sexual intercource and risk of symptomatic urinary tract infection in post-monopausal women. Journal General Internal Medicine. 2008;23:595-9.

20. Fahmi IA. Estimation of phenol content, antioxidant ability and antibacterial activity of two ginger zingiber officinale varieties. New York Science Journal. 2014;7(4):10-6.

21. Hasan HA, Ayad MRR, Basama MAR and Bassam ARH. Chemical compotition and antimicrobial activity of the crude extracts isolated from zingiber officinale bay different solvents. Pharmaceutica Analytica Acta. 2012;3(9).
22. Naoko T, Yoshihiro I, Hajime $\mathrm{H}$ and Akihito T. Effects of two terpene alcohols on the Antibacterial activity and the mode of action of farnesol against Staphylococcus aureus. Molecules. 2008;13:306976.

23. Cushnie TPT and Andrew JL. Antimicrobial activity of flavonoid. International Journal of Antimicrobial Agents. 2005;26:343-56.

24. Suhad AA, Iman IJ and Hamssah EAW. Study the antibacterial activity of zingiber officinale roots against some of pathogenic bacteria. AlMustansiriya Journal Science. 2012;23(3).

25. Nada KKH, Zainab KA, Zainab AGC. Antibacterial activity of the aquatic ekstract of fresh, dry powder ginger, apple vinegar extract of fresh ginger and crud oil of ginger against different type of bacterial in hilla city. International Journal of Pharmacy and Pharmaceutical Sciences. 2014;6(5):414-7.

26. Orlando A. Abreu and Guillermo Barreto. Antiadhesive effect of plant compounds in bacteria. phytochemicals as nutraceuticals-global approaches to their role in nutrition and health. Available from: http://www.intechopen.com/books/phytochemicals -as-nutraceuticals-global-approaches-to-their-roleinnutrition-and-health/antiadhesive-antibacterialeffect-of-plant-compounds. 2012.

27. Tejasari. Evaluation of ginger bioactive compounds in increasing the ratio of t-cell surface molecules of CD3+CD4+: CD3+CD8+ invitro. Malaysia Journal Nutrition. 2007;3(2):161-70.

28. Akintobi OA, Onoh CC, Ogele JO et al. Antimicrobial activity of Zingiber officinale (Ginger) extract against some selected pathogenic bacteria. Nature and Science Journal. 2013;11(1). 